\title{
高瀬川の複断面河道部における塩水遡上特性 \\ CHARACTERISTICS OF SALT WATER INTRUSION IN COMPOUND CHANNEL OF TAKASE RIVER
}

\author{
藤原広和 1 ・石川忠晴 $2 \cdot$ 西田修三 3 ・鶴田泰士 4 ・沢本正樹 5 \\ Hirokazu FUJIWARA, Tadaharu ISHIKAWA, Shuzo NISHIDA, \\ Yasushi TSURUTA and Masaki SAWAMOTO

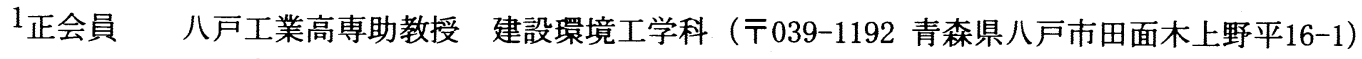 \\ 2 フェロー 工博 東京工業大学大学院教授 総合理工学研究科 \\ （广226-8502 神奈川県横浜市長津田町4259） \\ 3 正会員 工博 大阪大学大学院助教授 工学研究科（广565-0871 大阪府吹田市山田丘2-1) \\ 4 学生会員 工修 東京工業大学大学院 総合理工学研究科 (†226-8502 神奈川県横浜市長津田町4259) \\ 5フェロー 工博 東北大学大学院教授 工学研究科（テ980-8579 宮城県仙台市青葉区荒巻字青葉）
}

\begin{abstract}
The Takase River is important in the southeast of Aomori Prefecture and its estuary is typical tidal river. Mixing of salt-water intrusion in compound channel is very complicated. The field measurement is performed to study the mixing characteristics in the compound channel of the Takase River estuary. The salinity concentrations are measured by the thermometers and by the salinometers in 29 stations of the field. The water temperature is changed into the salinity concentration. The results of this study showed that patterns of the horizontal salinity mixing in the compound channel at flood tide is different from those at ebb tide.
\end{abstract}

Key Words : tidal portion, field observation, compound channel, estuarine density current

\section{1.はじめに}

感潮河川は, 海水性・淡水性の生物が入り交じった豊 かな生態系を有し，近年は貴重な自然環境を保全しよう とする動きが強まっており, バランスを考えた地域開発 が望まれている. そのためには感潮河川における自然環 境の成り立ちについての理解を深める必要がある. 本研 究は感潮河川における塩水混合の実態把握を目的として, 高瀬川河口部の複断面水路部に着目し, 塩分および氷温 を測定し，塩水の混合過程，特性を明らかにしようとし たものである.

青森県東南部に位置する高瀬川河口部は，汽水湖であ る小川原湖と太平洋を結ぶ感潮河川である. 小川原湖一 の塩分流入は, 高瀬川の塩分遡上と混合, 湖の斜面密度 流, 湖流による物質輸送, 鉛直混合という過程を形作っ ている. 高瀬川の塩分遡上については石川ら ${ }^{1)}$, 藤原ら ${ }^{2)}$, 西田・中辻 ${ }^{3)}$ の研究がある. 小川原湖の斜面密度 流に関しては長尾ら ${ }^{4)}$ の研究がある. 湖流による物質輸 送に関しては鶴田・石川 ${ }^{5)}$ の研究がある.

\section{2. 複断面水路密度流の特性}

著者らは，高瀬川河口部における現地観測結果 ${ }^{6}$ など から, 複断面河道に起因する複雑な流動形態が生じてい ることに着目し，実験的に複断面水路密度流の水理特性 などを明らかにしてきた. 実験では複断面水路における 塩水混合は、潮汐による河口部の水位変化により、塩水 は先に低水路を混合しながら侵入してくる. このとき低 水路部では内部波が発生する. その後、低水路と高水敷 間の流速差による水平shearにより水平方向への混合が 促進される ${ }^{7)}$. そのため、複断面水路では単断面水路よ り混合量が大きいことが確認されている2).

\section{3. 锶測概要}

\section{(1) 現地概要}

图一1は青森県東南部に位置する小川原湖および高瀬 川河口部の概要図である. 高瀬川河口部は, 汽水湖であ る小川原湖と太平洋を結ぶ感潮河川である. 高瀬川は流 
域面積866. $9 \mathrm{~km}^{2}$ ，幹線流路延長 $63.7 \mathrm{~km}$ で，八甲田山系八 幡岳に源を発する 1 級河川である. 小川原湖は湖面積 $63.2 \mathrm{~km}^{2}$, 平均水深 $11 \mathrm{~m}$ である. 河口より約 $5.7 \mathrm{~km}$ 上流に 放水路があるが，洪水時以外はゲートが閉められている ので, 海水は通常高瀬川を経由し, 侵入する. 小川原湖 の年平均水位は約T. P. $+40 \mathrm{~cm}$ である.

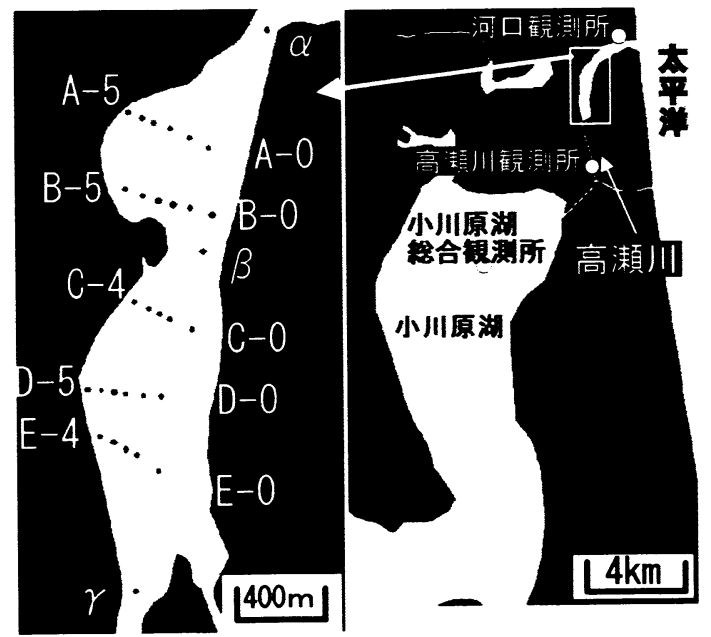

図一1 小川原湖周辺および測点位置

\section{（2）钼測方法}

図ー1の高瀬川河口の複断面河道部において，1999年 8月7日〜8月 14 日の期間に塩分濃度および水温の測定を 実施した。測点は $\alpha, \mathrm{A}-0, \mathrm{~B}-0, \beta, \mathrm{C}-0, \mathrm{D}-0, \mathrm{E}-0$, $\gamma$ の澪筋部と $A-1 \sim A-5, B-1 \sim B-5, C-1 \sim C-4, D-1 \sim D-5$, $\mathrm{E}-1 \sim \mathrm{E}-4$ の浅瀬で寒施された（図一 1では測点番号が省 略されているが，例えばA-0からA-5に向かってA-0の隣 の点がA-1, その隣の点がA-2, その隣の点がA-3である. 他の省略されている $\mathrm{B}, \mathrm{C}, \mathrm{D}, \mathrm{E}$ 測線についても同様 である．）．淎筋では水面から $0.3 \mathrm{~m}$ (上層)，水面から $1.3 \mathrm{~m}$ (中層)，および水面から $2.3 \mathrm{~m}$ （下層）の位置にセ ンサーが取り付けられている. また, 浅瀬では河床から

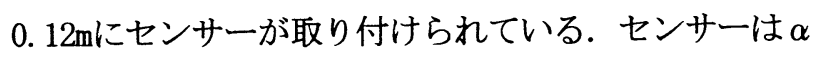
上層, $\alpha$ 中層, $\beta$ 中層, $\gamma$ 中層, $\mathrm{B}-3, \mathrm{D}-3$ 測点の 6 点に水温・塩分計（（株）アレック電子, $\mathrm{MDS}-\mathrm{C}$ T）を設置した， $\alpha$ 下層， $\beta$ 上層・下層， $\mathrm{C}-0$ 上層・中 層・下層， D-0上層 - 中層 -下層， $\gamma$ 上層 -下層の測点 に水温計（（株）アレック電子, MDS-T）を設置し た. $\mathrm{E}-0$ 上層・中層・下層および浅瀬の測点に水温計 (Onset社, StowAway “TidbiT”) を設置した.8月7日 ～8月8日に測定器はセットされ，8月14日朝まで水温, 塩分は1分毎に計測された。ただし，A-0，B-0測点は測 定器を発見できず回収できなかったのでデータは無い.

測点の位置はDGPSとセオドライトを併用して求めた.

また，图一2は観測地域の河床横断面図である. 今回の 観測では河口の水位がT. P. 值で最大 $80 \mathrm{~cm}$ 超え, 最小 で-20cm位であったので, 浅瀬部分では干上がることも あった.

また，観測データの検討のため，建設省で観測されて
いる水位（河口，高瀬川，小川原湖の各観測所）と塩分 （高瀬川観測所）を利用した.

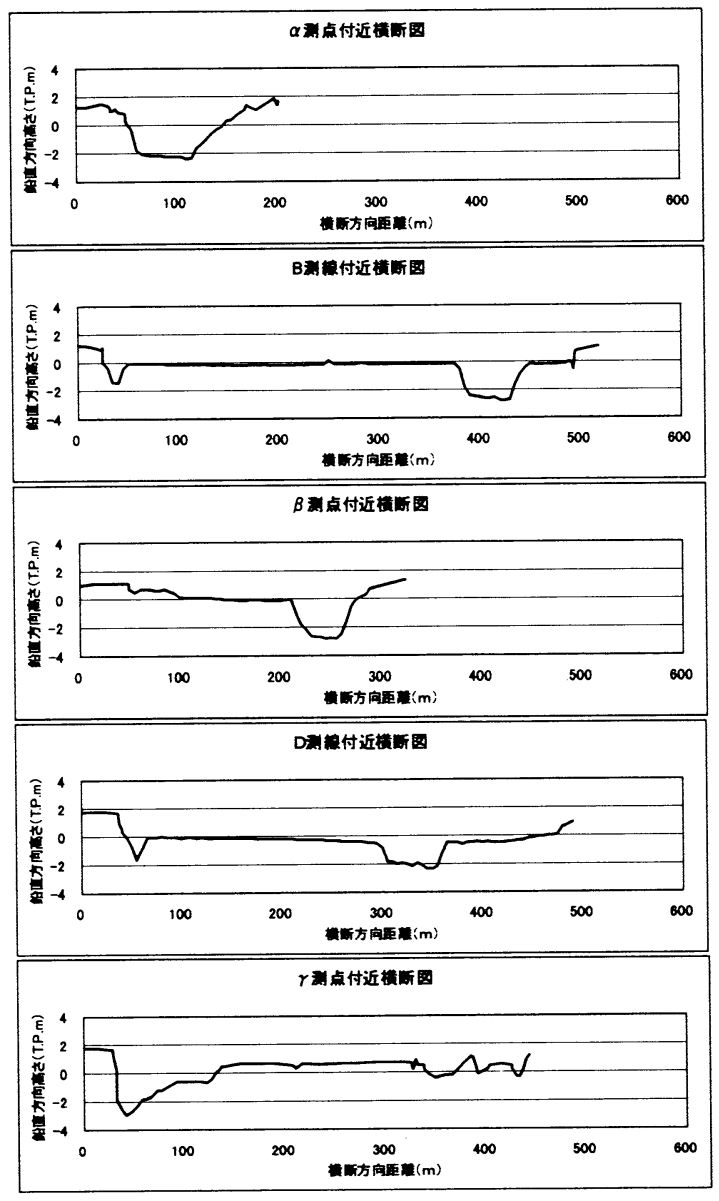

図-2 河床横断面図

\section{4. 锥測結果}

\section{(1) 钼測時の概要}

图一3は観測期間における建設省の河口観測所，高瀬 川観測所，小川原湖総合観測所で測定された水位時系列 である. 8 月 10 日〜 12 日が大潮にあたる.この時期に降 雨はほとんどなかった. 图一4は河口から $5.5 \mathrm{~km}$ 上流の 高瀬川観測所で測定された塩分の時系列である. 本研究 では主として大潮直前の 8 月 8 日〜 9 日と大潮時の 8 月 11日〜 12日の測定データを使用し，高瀬川複断面河道部 の塩水挙動について考察する.

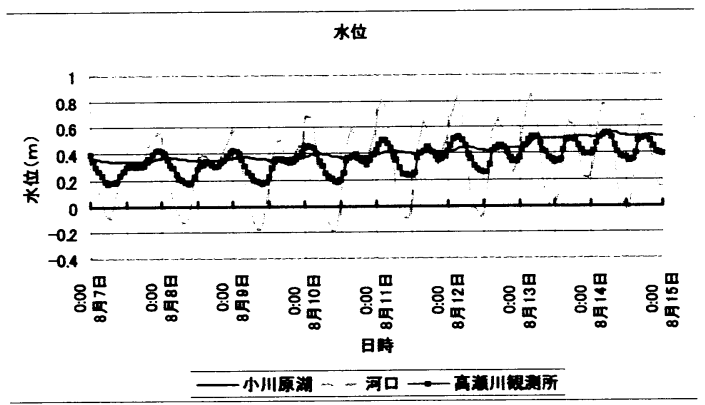

図一3 河口，高瀬川，小川原湖の水位時系列 


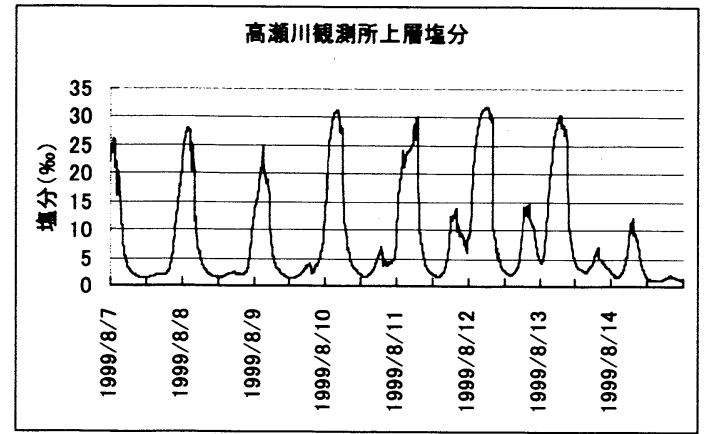

図-4 高瀬川観測所の塩分時系列

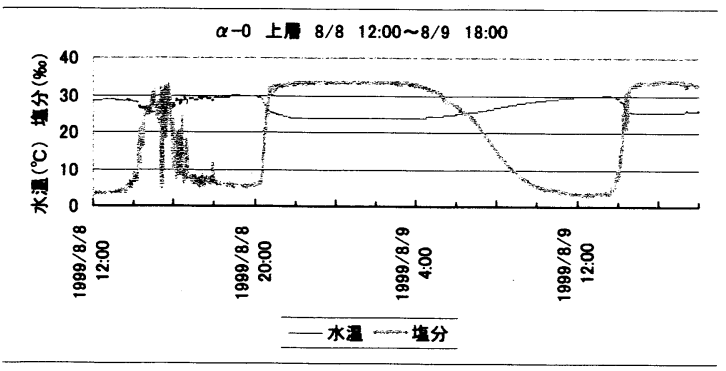

（a） $\alpha$ 上層（下流の澪筋）

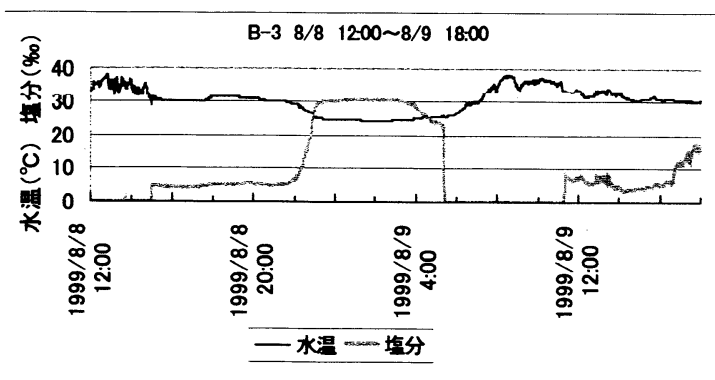

(b ) B - 3 (下流の浅瀬)

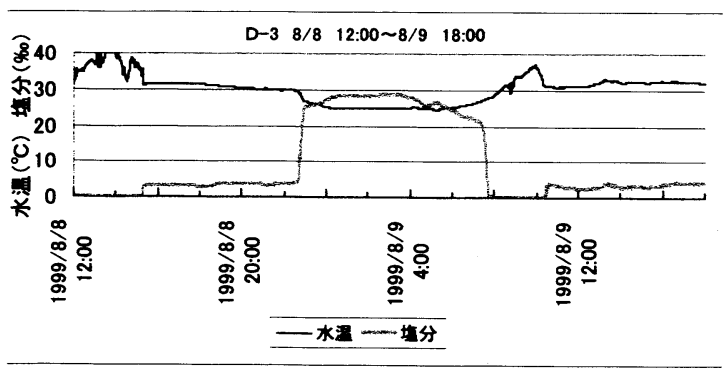

（c） D-3 (上流の浅瀬)

図ー5 水温と塩分の測定結果（8月8日～9日）

\section{(2) 測定結果}

图一 5 は水温・塩分計による8月8日〜 9 日の $\alpha$ 上層, B-3，D-3の塩分濃度と水温の測定結果である. 图一6は 水温・塩分計による8月 11 日〜 12 日の $\alpha$ 上層, B-3, D-3 の塩分濃度と水温の測定結果である. これらより多少の 時間差は各地点であるが, 水温が下がるとき塩水が侵入 してきており，水温と塩分濃度は相関があることがわか る. 図一5より塩水侵入前は浅瀬でも干上がっておらず 河川水が存在していることを示す．その後，8月9日 5 時 以降に $\mathrm{B}-3, \mathrm{D}-3$ で塩分濃度が $0 \%$ になっているこ

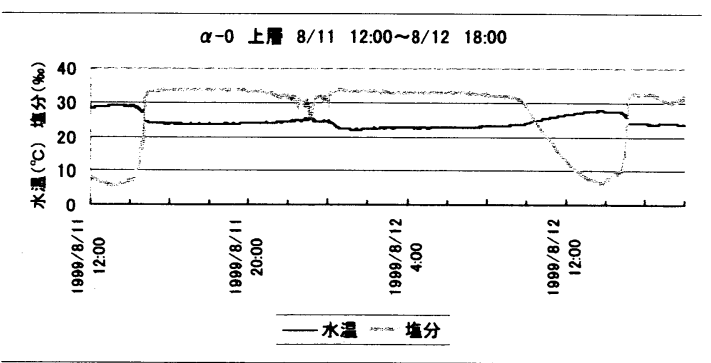

（a） $\alpha$ 上層 (下流の洅筋)

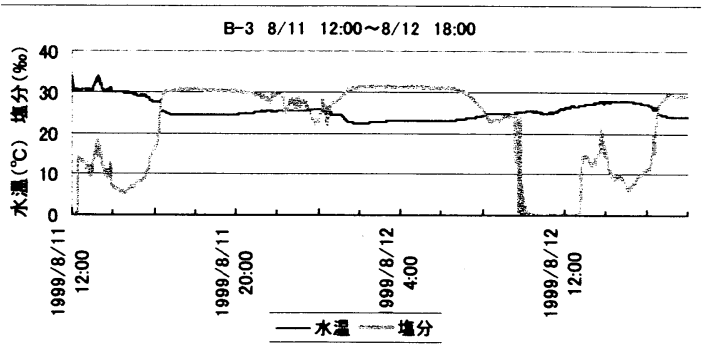

(b ) $\mathrm{B}-3$ (下流の浅瀬)

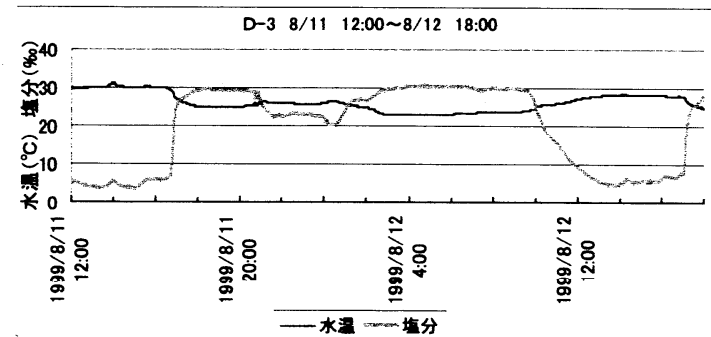

（c） $\mathrm{D}-3$ (上流の浅瀬)

図一6 水温と塩分の測定結果（8月11日～12日）

\section{とから浅瀬では干上がっていることがわかる.}

图一7は図一5の水温・塩分計で測定した $\alpha$ 上層測点 の水温と $\beta, \gamma$ 各上層の水温計の測定值を重ねてプロッ トしたものである.これより淎筋では $\alpha$ と $\beta, \gamma$ で時間 差はあるが，塩水が侵入するときと流出するときは水温 の低下と上昇がみられ， $\alpha$ の水温と塩分の相関関係を他 の澪筋の水温測定点に使用可能である. また, 浅瀬の場 合においても，例えば $\mathrm{B}-3$ の水温・塩分計の水温と $\mathrm{A}$ -3 の水温計の測定值を重ねてプロットすると图一8 ようになり, 時間差はあるが, ほぼ一致しているので, $\mathrm{B}-3$ の水温と塩分の関係を他の $\mathrm{A}$ 測線， $\mathrm{B}$ 測線の塩分 変換に利用可能である. 同様に $\mathrm{D}-3$ 測点の水温と塩分 の関係を $\mathrm{C}$ 測線, $\mathrm{D}$ 測線, $\mathrm{E}$ 測線に利用可能である.

\section{(3) 水温之塩分濃度の相関}

图一 9 は $\alpha$ 上層, $\mathrm{B}-3, \mathrm{D}-3$ 測点の 8 月 8 日逆流 $8 / 11 \quad 1200 \sim 8 / 1218: 00 \alpha \beta \quad \gamma$

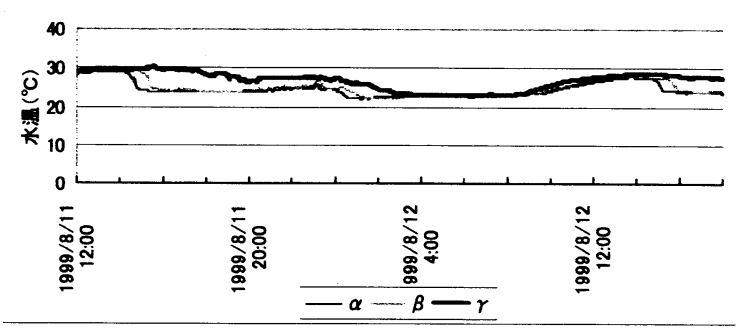

図一7 $\alpha, \beta, \gamma$ の水温時系列（8月11日～12日） 
B-3 $8 / 11 \quad 12: 00 \sim 8 / 12 \quad 18.00 \quad B-3 と A-3$

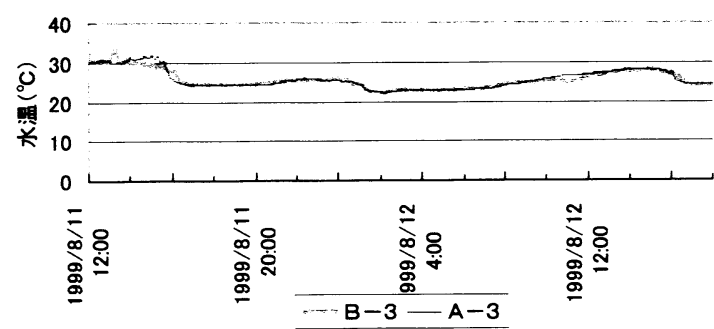

図一8 $\mathrm{B}-3$ と $\mathrm{A}-3$ の水温時系列(8月11日〜12日)

$\alpha-0$ 上扈 $8 / 8 \quad 20: 15-8 / 8 \quad 21.22$

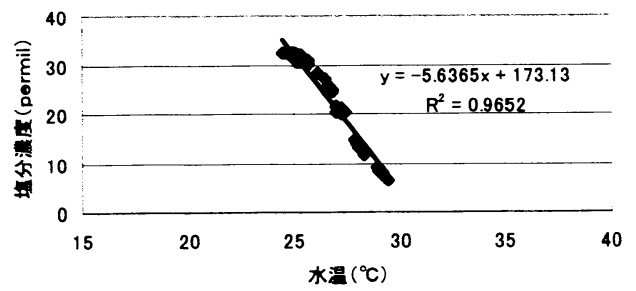

（a） $\alpha$ 上層（下流の澪笳）

$\begin{array}{lllll}B-3 & 8 / 8 & 21: 51-8 / 8 & 23: 18\end{array}$

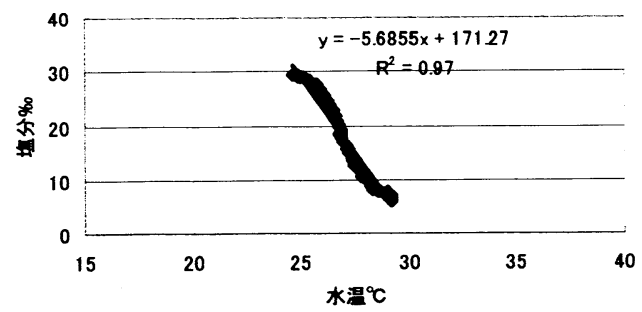

(b ) $\mathrm{B}-3$ (下流の浅瀬 $)$

$\begin{array}{lllll}D-3 & 8 / 8 & 22: 42 & -8 / 8 & 23.01\end{array}$

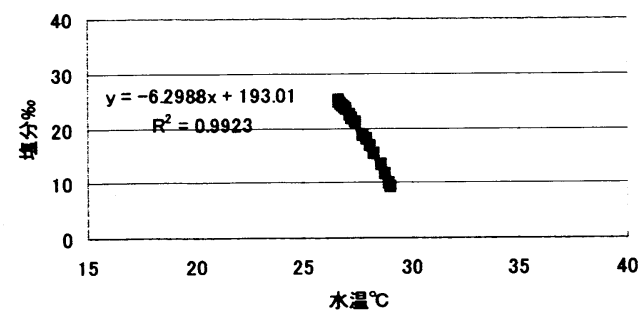

（c） D-3（上流の浅瀬）

図-9 逆流時の相関

時の水温と塩分の相関である. 回帰式を

$$
\mathrm{y}=\mathrm{a} \cdot \mathrm{x}+\mathrm{b}
$$

( $\mathrm{y}$ : 塩分浱度 $(\% 0), \mathrm{x}$ : 水温 $\left({ }^{\circ} \mathrm{C}\right), \mathrm{a}, \mathrm{b}$ : 倸 数）の直線回帰とするとそれぞれの測点で係数 $\mathrm{a}, \mathrm{b}$ は 異なる. また，順流時と逆流時でも係数は異なる. そこ で, 塩水侵入時, 流出時毎に毎回係数 $\mathrm{a}$ を求め, その時 間変化を追ってみた. 图一10は侵入時と流出時の係数 a の変化である. 澪筋と浅瀬で分けて検討してみた. これ より，澪筋では上層，中層に関係せず，時間のずれはあ るが, 係数a は同じ時間帯ではほぼ一致していると言え る. また, 浅瀬でも位置的には上流側（D-3）と下流
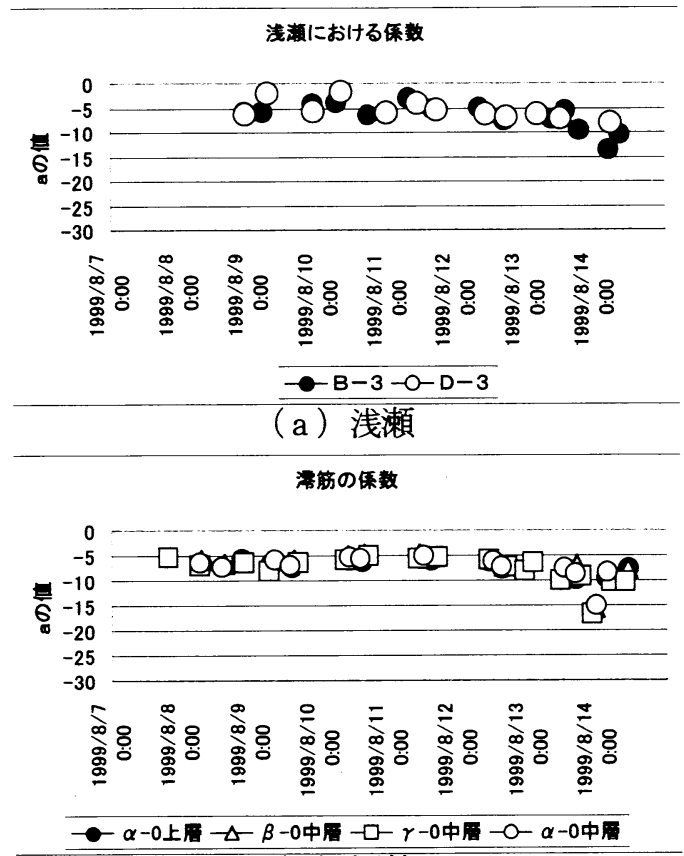

(b) 澪筋

図-10 係数 $\mathrm{a}$ の変化

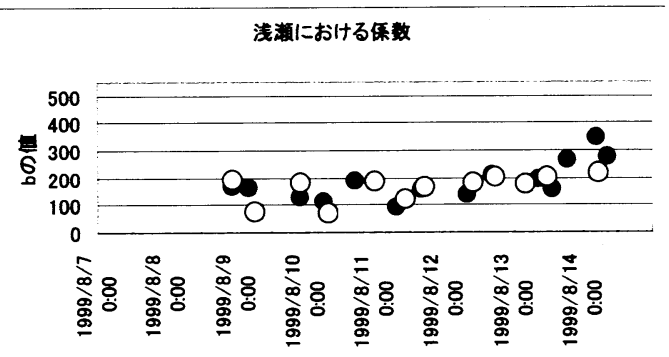

- $-B-3-O-D-3$

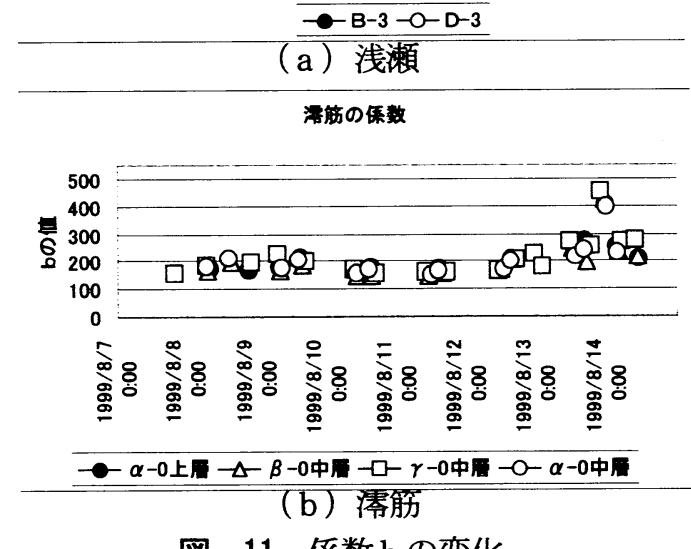

図-11 係数 $\mathrm{b}$ の変化

側（B-3）で離れてはいるものの係数 $\mathrm{a}$ はほぼ近い值 を示している. 图一11は図-10と同様にしてプロットし た係数 $\mathrm{b}$ の時間変化であるが, 係数 $\mathrm{a}$ と同様なことが言 える. したがって, 淎筋では $\alpha$ 上層の回帰式を他の澪筋 上層 $(\beta, \gamma, \mathrm{C}-0, \mathrm{D}-0, \mathrm{E}-0)$ で利用できる. また, 浅 瀬では，上流側 $(\mathrm{D}-3)$ は上流側のフィールド（C, D， E測線）で回帰式を利用できる．下流側（A，B測 線）も同様である.（2）で述べたように各測点間で澪筋 では時間のずれはあるが，それぞれの回㷌式を当てはめ る時間を水温の時系列から求め使用寸れば水温から塩分 
濃度に変換可能である.

澪筋（ $\alpha$ 上層）の回帰式と浅瀬 $(\mathrm{B}-3, \mathrm{D}-3)$ の 回帰式を各塩水侵入時と各塩水流出時の時間帯毎に $1 つ 1$ つ分けて求め, それらを各測点の水温にフィールド毎, 時間帯毎に当てはめて変換した塩分の時系列の1例が図 -12であり， $\mathrm{E}-3, \mathrm{C}-0$ 上層の測定された水温と水 温から变換した塩分濃度の時系列を示寸.

$E-3$ 水温と㙁分 8月11日12.00 12日18.00
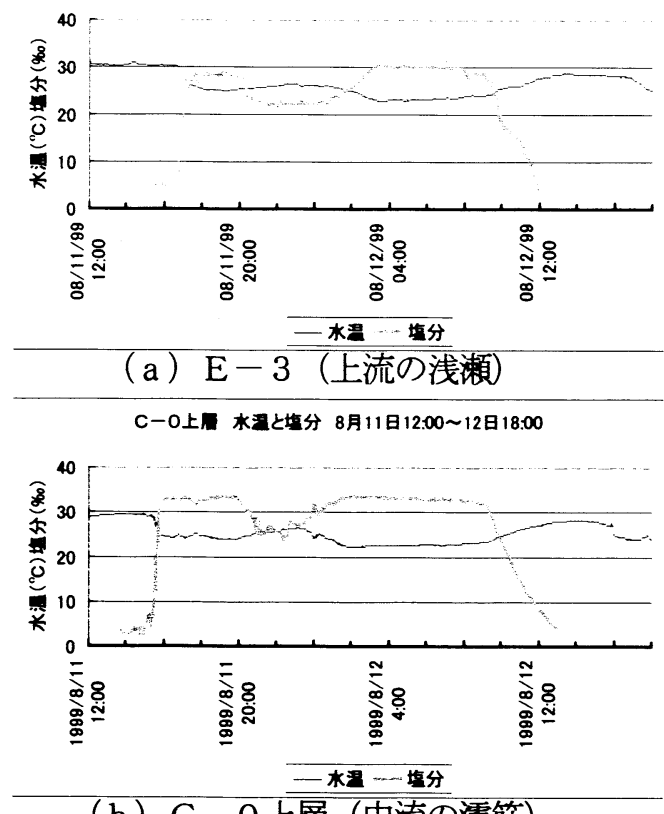

（b） $\mathrm{C}-0$ 上層 (中流の澪筋)

図一12 水温と変換した塩分の時系列

\section{（4）塩分浱度の変化パターンについて}

\section{a) 高高潮のみによる塩水侵入の場合}

图一13は(3) で得られた各測点の塩分濃度から求めら れた 8 月 8 日の塩水遡上時における塩分濃度の等值線図 の変化である. 図の上方側が下流（河口側）で，下方側 が上流（小川原湖側）になる．等値線は澪筋を中心に測 点のある左岸側のみ記入してある. これより，河口水位 の上昇とともに澪筋を中心に塩水が侵入しており，複断 面水路部の浅瀬で混合しながら上流に侵入しているのが わかる. この後, 複断面河道部全体が塩分港度 $25 \%$ 以上 になる. この塩水侵入は低高潮のときに一度澪筋で濃度 変化があるが，浅瀬まで達することなく高低潮により一 度河口近くまで海水が引き，再び高高潮に向かって塩水 が侵入している. このときの小川原湖の水位は建設省小 川原湖総合観測所のデータによれば， T. P. +0. 35〜0.37 $\mathrm{m}$ であり平常時に比べ低い.

图一14は図ー13で侵入した塩水の流出過程である. 河 口水位の低下とともに河口側入塩水は流出していく．図 -14（b），（c），（d）の白い地域は急激に濃度が 下がっているように見えるが，これは干上がっている 状態を表している. 従って塩水の流出は徐々に塩分濃度 が小さくなるのではなくて，混合水がそのまま河口へ流 出する. この後, 上流, 下流の浅瀬は完全に干上がり,

澪筋部にだけ河川水が流れている状況になる.

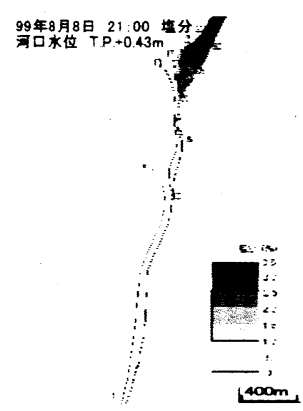

(a) 8月 8日21:00 河口水位 T.P. $+0.43 \mathrm{~m}$

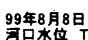

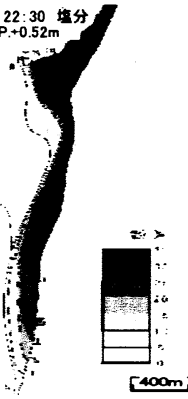

(c) 8 月 8 日22:30

河口水位 T.P. $+0.52 \mathrm{~m}$

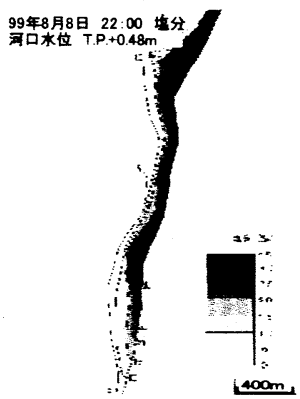

(b) 8月 8日22:00 河口水位 T.P. $+0.48 \mathrm{~m}$

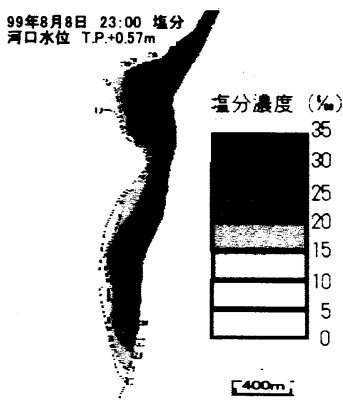

(d) 8月 8日23:00

河口水位 T.P. $+0.57 \mathrm{~m}$ 図-13 塩水遡上時の塩分の等値線図（8月8日）

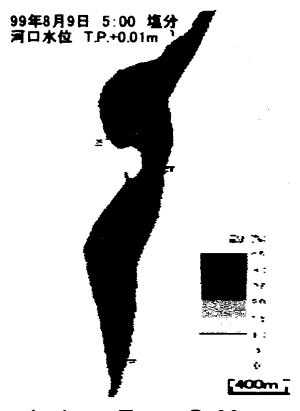

(a) 8月9日5:00 河口水位 T.P. $+0.01 \mathrm{~m}$

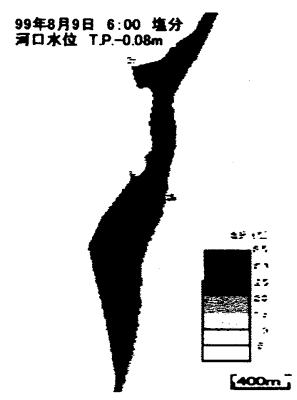

(c) 8 月 9 日6:00 河口水位 T.P. $-0.08 \mathrm{~m}$ 口水位 T.P. $-0.13 \mathrm{~m}$ 図-14 塩水流出時の塩分の等值線図 (8月9日)

\section{b) 低高潮と高高潮による塩水僈入の場合}

图一15は8月11日〜12日の塩水の遡上過程である.こ のときの小川原湖の水位はT. P. +0. 40〜0. 43mであり， 潮汐は大潮にあたる．澪筋に塩水が侵入し，浅瀬で混合 していく状況は8月 8 日と同じであるが，下流側の浅瀬 と上流側の浅瀬での混合に時間差がある. 図一13では明 確な時間差は無かった. 図一15（a）〜（d）は低高潮 


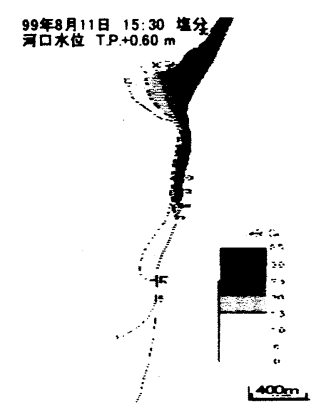

(a) 8月11日15:30 河口水位 T.P. $+0.60 \mathrm{~m}$

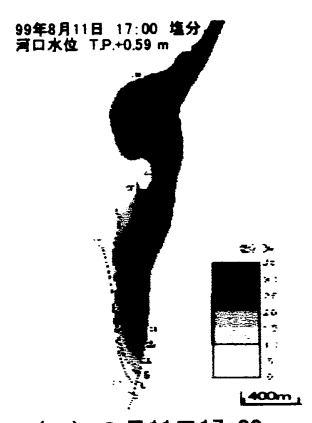

(c) 8月11日17:00 河口水位 T.P. $+0.59 \mathrm{~m}$

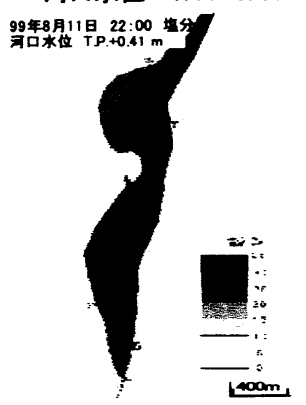

(e) 8月11日22:00 河口水位 T.P. $+0.41 \mathrm{~m}$

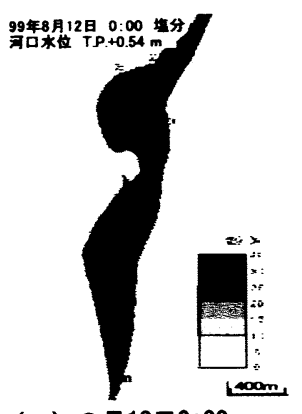

(g) 8 月 12 日0:00

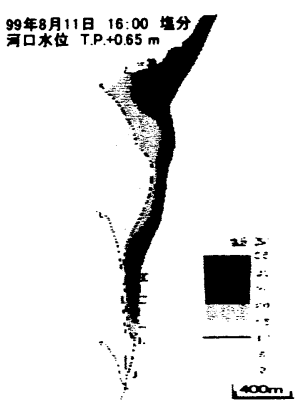

(b) 8月11日16:00 河口水位 T.P. $+0.65 \mathrm{~m}$

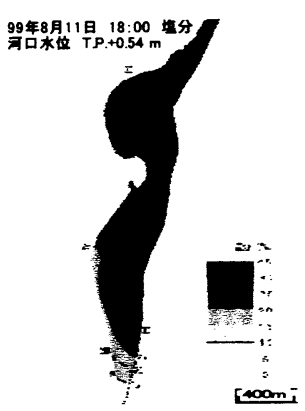

(d) 8月11日18:00 河口水位 T.P. $+0.54 \mathrm{~m}$ 99年8月11日

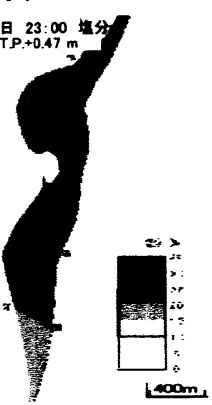
(f) 8月11日23:00 河口水位 T.P. $+0.47 \mathrm{~m}$

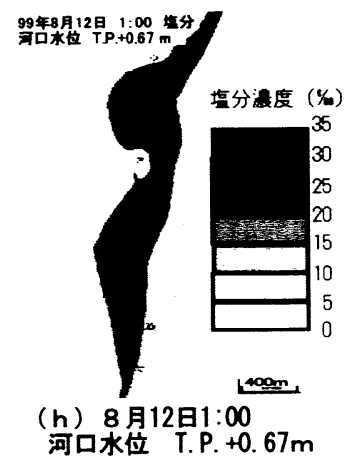

図ー15 塩水遡上時の塩分の等值線図（8月11～12日）

時の塩水侵入であり，8月 8 日の高高潮時の河口水位よ りも $8 \mathrm{~cm}$ 程高い. 図一15（e）～( f ) は高低潮のため, 侵入した塩分が河口に向かって引いているときである. このとき混合水が全て流出するわけではなく, 高高潮に 向かい再び河口の水位は上昇するので, 浅瀬に混合水が 残った状態で，2回目の塩水侵入が起こる. これが図一 15 （g）〜（h）である. この後, 浅瀬でもほぼ全域が 塩分濃度 $30 \%$ 以上となる. 図一4からも，このときの塩 水遡上は観測期間の中でも塩分濃度が最も大きく, 河口 から $5.5 \mathrm{~km}$ 上流でも $30 \%$ 以上に達している. これらより，

図一3の観測期間における小川原湖の水位上昇は降雨に よるものではなく，塩水が大量に遡上したためのもので あることがわかる.

\section{5. おわりに}

塩水と淡水の水温差が大きい夏季の高瀬川では、比較 的広範囲の塩水侵入の現地計測においても，塩分濃度と 水温の相関の基本となる個所を選定し塩分計を設置すれ ば，水温計の測定値から塩分濃度に変換しても現象をよ く表せることができることがわかった．観測結果から， 複断面河道部における水平方向の塩分侵入と塩分流出の パターンを示すことができた．また、潮汐の波形パター ンにより塩分侵入パターンも変化することが確認できた. 今回の観測結果にある浅瀬での塩水侵入時の混合は、過 去の実験結果 ${ }^{7}$ と比較すると、低水路と高水敷間の水平 shearによるものと考えられる. 混合後の塩水の流出過 程に関する実験は実施していないので、比較することは できない，今後、さらに検討して行きたいと考えている.

碀辞 : 本研究を行うにあたり, 建設省東北地方建設局高 瀬川工事事務所からは貴重なデータの御提供と観測に際 し御高配を頂いたことに感謝いたします．現地観測と データ整理では八戸高専学生 八木橋丈夫君と北城正樹 君に協力頂いたことに感謝します。.また, 本研究は文部 省科学研究費補助金基盤研究(B)（研究代表者 石川忠 晴）による研究の一部であることを付記する. 記して謝 意を表します。

\section{考文率}

1)石川忠晴・板井雅之・小沢康彦：小川原湖に侵入する塩分の 計算モデルの検討，水工学論文集，第35巻，pp. 191-196, 1991. 2) 藤原広和 ・沢本正樹 - 田中博通 : 複断面および単断面水路に おける密度流の混合特性の相違について, 水工学論文集, 第41 巻, pp. 515-520, 1997.

3) 西田修三・中辻啓二 : 緩混合河川における流量と塩分輸送量 の算定, 水工学論文集, 第43巻, pp. 869-870, 1999.

4) 長尾正之 - 石川忠晴・長島伸介 : 小川原湖に発生する傾斜プ ルームの現地観測と連行俰数の推算, 土木学会論文集证. 579/ II-41, pp. 105-114, 1997.

5)鶴田泰士・石川忠晴 : 小川原湖における風速分布の現地観測, 水工学論文集, 第43巻, pp. 1043-1048, 1999.

6) 藤原広和・田中博通 : 高瀬川感潮域の現地観測による水理特 性について, 水工学論文集, 第37巻, pp. 171-176, 1993.

7)藤原広和・沢本正樹 - 神山尚人 : 複断面水路における河口密 度流の混合特性, 海岸工学論文集, 第42巻, pp. 416-420, 1995.

(1999. 9. 30受付) 